\title{
Study of Selection of Bus Mode and Rail Train Surabaya - Malang
}

\author{
Haris Muhammadun ${ }^{1}$, Sindiah Bagus Mahendra Tama1, Wateno Oetomo², \\ Sri Wiwoho Mudjanarko ${ }^{3 *}$, \\ 17 Agustus 1945 University ${ }^{1}$, Narotama University ${ }^{2}$ \\ hardun.wtu@gmail.com. ${ }^{1}$ profwateno.wiro@gmail.com ${ }^{2}$ sri.wiwoho@narotama.ac.id $^{3 *}$
}

\begin{abstract}
The need for transportation facilities and infrastructure that is quite large in the city of Surabaya to the city of Malang is the impact of population growth and increased activity in the city. To support economic, social, trade and education activities between the two cities, public transportation facilities are needed that can meet the needs of the community in terms of comfort and safety. Fulfillment of comfort factors in the use of public transportation such as cheap travel costs, speed of travel time, and accuracy of operational schedules, is expected to increase the interest of travelers to use public vehicles more often than private vehicles. The analysis method used, among others, Descriptive Analysis aims to identify the characteristics of users of the SurabayaMalang and bus modes, then the Logistic Regression Analysis and Binomial Logit Difference Analysis aim to Obtain a model of selection of bus and train modes in the Surabaya-Malang route, then proceed Sensitivity Analysis which aims to determine the sensitivity of the model of the response of the traveler in determining the choice if there is a change in each attribute of the trip. The results of logistic regression analysis and binomial logit difference, it can be concluded that, attribute / variable X2 (travel time) is the attribute / variable that most influences the mode selection. The sensitivity analysis results can be concluded as follows: Sensitivity to travel costs, the possibility of respondents prefer to use the train mode is greater than the bus. Sensitivity to time, the possibility of respondents prefer to use the train mode is greater than the bus. Sensitivity to the departure schedule (headway), the possibility of respondents choosing to use the train mode will be greater than the bus, if the difference in the headway is between 90 165 minutes. However, if the difference in headway is above 165 minutes, then the respondent will switch to choosing the bus mode.
\end{abstract}

Keywords: modal choice, travel cost, travel time, departure schedule

\section{INTRODUCTION}

Transportation is the transfer of people or goods from one place to another by using a vehicle that is driven by humans or machines. Transportation is useful to make it easier for humans to carry out daily activities. In general, transportation has the function to smooth the flow of goods and people and support development.

The problems of land transportation in East Java include the lack of fulfillment of transportation service facilities and infrastructure, the need for roadworthiness that does not meet standards and the imbalance of vehicle growth rates by increasing road capacity and not yet optimal interregional mass transportation (RPJMD of East Java Province, 2019-2024). The need for transportation facilities and infrastructure that is quite large in the city of Surabaya to the city of 
Malang is the impact of population growth and increased activity in the city. To support economic, social, trade and education activities between the two cities, transportation facilities that can meet the needs of the community are needed in terms of comfort and safety.

Based on the 2012-2032 East Java Tatrawil Document, the Surabaya-Malang movement is the dominant movement with the largest number of movements of 10-20 million movements in a year. That is because Surabaya and Malang are the two largest cities in East Java, which causes high movements between the two. The high movement of the Surabaya-Malang route is dominated by private vehicles due to the low interest in using public vehicles such as trains and buses.

Growth in the number of motor vehicles in East Java ranges between $5-10 \%$ per year. For two-wheeled vehicles and four-wheeled vehicles in the city of Surabaya, which on average experienced an increase of $7.03 \%$ per year, then Malang, which is the second city and district after the city of Surabaya, which has the most vehicles with an average increase of $5.65 \%$ per year (Priyambodo. 2018).

Travel agents prefer to use private vehicles compared to using public transportation due to the lack of public transportation facilities in fulfilling the desires of the traveler (Rangkuti \& Sugiri, 2014). Fulfillment of comfort factors in the use of public transportation such as cheap travel costs, speed of travel time, and accuracy of operational schedules, is expected to increase the interest of travelers to use public vehicles more often than private vehicles.

Based on these problems, it is important to make efforts to further improve the improvement of Bus and Rail services in the Surabaya-Malang route. This study aims to determine the factors that influence the traveler in choosing the Surabaya-Malang route mode, which is expected to be able to provide input for the development of train and bus service performance in the future.

\section{LITERATURE REVIEW}

\section{The Role of Transportation}

Transportation has an important role and strategy in national development considering that transportation is a means to accelerate the wheels of the economy, strengthen unity and integrity and influence almost all aspects of life. The importance of transportation as the pulse of economic life, social economy, politics, and defense and security has two dual functions, namely as a supporting element and as a driving element. As a supporting element, transportation functions to provide effective transportation services to meet the needs of various sectors and drive national development. As a driving force, transportation functions to provide effective transportation services to open isolated areas, serve remote areas, stimulate the growth of disadvantaged and underdeveloped areas (Tamin, 2000).

\section{Transportation Modeling}

The model is a tool or media that can be used to reflect and simplify a reality (the actual world) in a measurable or simplified reality to get certain goals, namely explanation and deeper understanding and for forecasting purposes. The more similar a model is to reality, the more difficult it is to make that model. So, modeling is a quantitative approach that is carried out to get 
clearer and measurable explanations or pictures about the transportation system. Transportation modeling consists of several types (Tamin, 2000), including:

a. Physical model, which is a model that shows and explains the same object with a smaller scale so that a clearer and more detailed and measurable picture of the object's behavior is built on the actual scale. For example: architect models (houses, housing, malls, etc.) and engineering models (regional, city, regional development models, etc.)

b. Map and diagram models, namely models that use lines (straight and curved), images, colors, and shapes as a medium for delivering information that shows the reality of the object. For example, contour elevation, slope of land, location of rivers and bridges, mountains, government administrative boundaries, and others.

c. Statistical and mathematical models, namely models that describe existing conditions in the form of equations and mathematical functions as media in an effort to reflect reality. For example, explaining the physical aspects, socio-economic, and transportation models. The advantage of using mathematical models in transportation planning is that when making formulations, calibrations and their use, planners can learn a lot through experiments, about the behavior and internal mechanisms of the system being analyzed.

d. Descriptive and normative models, where descriptive models are models that try to explain the behavior of existing systems, while normative models are models that try to explain the ideal system behavior according to the wishes of the model maker.

\section{The Concept of Transportation Planning}

According to Tamin (2000) there are a number of transportation planning concepts that have developed to date and the most popular is the Four Step Transportation Planning Model (Four Step Models). The four models include:

a. Trip Generation Models, namely transportation modeling that functions to estimate and predict the number (number) of trips originating (leaving) from a zone / area / plot of land and the number (number) of trips coming / being attracted (headed) to a zone / area / plot of land in the future (plan year) per unit time.

b. Trip Distribution Models, namely modeling showing the number (number) of trips / originating from a zone of origin that spreads to many destination zones or vice versa the number (number of trips) / coming to collect to a destination zone that was originally from a number of origin zones.

c. Model of choice of transportation modes (Mode Choice models), namely the modeling or stages of the transportation planning process that serves to determine the burden of travel or find out the number (in the sense of proportion) of people and goods that will use or choose various modes of transportation available to serve a particular point of origin, for the sake of some specific travel purposes as well.

d. Route Assignment Models, which are models that show and predict the trip actors who choose various routes and traffic that connect the transportation network. 
Conceptually, the four-stage transportation planning can be described as Figure 1 below:

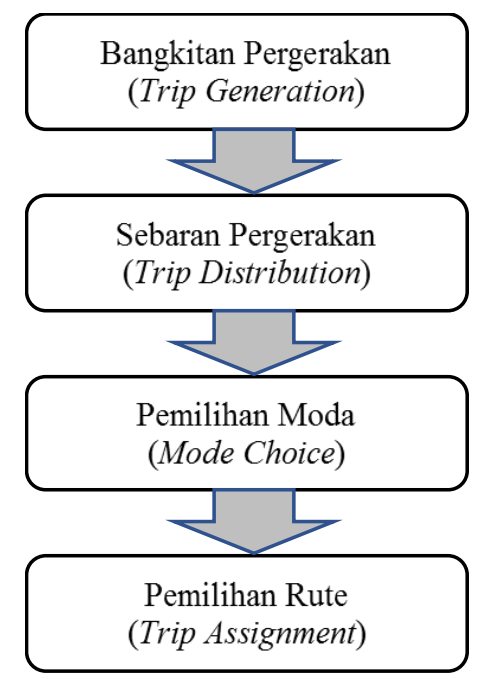

Figure 1. The concept of transportation planning

Source: Tamin, 2000

\section{Factors That Influence Mode Selection}

The modal choice model aims to find out the proportion of people who will use each mode. This process is carried out with the intention to calibrate the mode selection model in the base year by knowing the change in attributes that influence the mode selection. After the calibration process is carried out, the model can be used to predict modal selection by using attribute value values for the future (Tamin, 2000).

One factor that is considered strong influence on travel behavior or prospective users (trip maker behavior). Transportation system characteristics factor All variables that influence the behavior of the traveler relate to the performance of the transportation system services such as variables:

a. The relative time (length) of travel (relative travel time) starts from the length of time the vehicle waits at the stop (terminal), the time to walk to the terminal (walk to terminal time), and the time on the vehicle.

b. Relative travel costs (relative travel costs), ie all costs arising from traveling from origin to destination for all competing modes such as ticket prices, fuel, and others.

c. Relative service level (relative level of service), which is a variable that is quite varied and difficult to measure, for example, is a variable of comfort and pleasure, which makes it easy for people to change modes of transportation.

d. The level of access / connecting index / ease of achieving the destination.

e. The level of reliability of public transport in terms of time (on time / reliability), the availability of parking spaces and tariffs.

\section{RESEARCH METHODS}

In this research, the survey method used is Stated Preferences through online interviews with public bus and train users who have traveled from Surabaya to Malang. In this survey online 
interviews are conducted, which will later be included in the results of the questionnaire that was designed. From the survey results of the preferences of Bus and Train users, some information will be obtained, like:

a. Information about the characteristics of public transport users,

b. Travel behavior carried out by public transport users,

c. Public transport user preferences for predetermined attributes.

The following are the stages carried out in conducting surveys via the internet:

a. Formulation of the problem and its purpose

b. Making a questionnaire to retrieve data

c. Selection of prospective respondents

d. Submission of questionnaires to respondents

e. Determination of the location of the respondent's answer data storage.

The method developed by Isaac and Michael (1981) is a way to determine the number of samples that meet the requirements (1) the population is known; (2) at the level of error (significance level) of $1 \%, 5 \%$ and $10 \%$; and (3) specifically used for samples that are normally distributed.

Based on data from the Department of Transportation of East Java Province, an estimate of the total population of the study was obtained, resulting from the sum between the estimated number of Bus passengers and the estimated number of Railway passengers of the Surabaya - Malang route in a day amounting to 5,882 people.

To make it easier to determine the research sample, a sample determination table from Isaac and Michael is used as a reference in determining the sample sought. If referring to the table with a significance of $5 \%$ of the total population of 5882 people (through the estimated number of Train and Bus passengers in a day), a sample of 330 respondents can be generated.

The form of questions contained in the questionnaire form that will be surveyed includes two things, namely:

a. Questions will be focused on finding out the actual conditions and general characteristics of modal users about the socio-economic conditions of the modal users and information on the travel of modal users.

b. The question is focused on the respondents' preferences if there are several service attributes offered in the Bus and Train mode plan that are utility based on the conditions in reality. Variables used to measure utility, namely:

$>$ Travel costs (Cost), Costs that must be incurred for payment of transportation costs in units of rupiah per person, which is the cost of the terminal / station departing to the terminal / station of destination.

$>$ Travel time (time), Travel time of vehicles in hours, which is the travel time from the terminal / departure station to the terminal / destination station.

$>$ Headway, bus / train departure time between one fleet and the next.

Sensitivity analysis of attributes (travel cost, travel time, and headway) of one of the changes is done by assuming that this change does not affect other attributes. The sensitivity analysis procedure is carried out as follows:

1. Sort the value of the dependent variable according to the change group. 
2. Set the value of other independent variables using the average value.

3. Determine the value of the utility and probability in accordance with the changes made.

4. Draw a graph of the relationship between probability and the value of the dependent variable according to the group of changes made.

\section{ANALYSIS \& DISCUSSION}

The observed modes are Economy Bus and Train route Surabaya - Malang. The type of bus mode chosen to be observed is Economy Bus, while the selected Trains to be observed are the Upgrading Train and Tumapel Train. These modes were chosen because they have ticket rates that the difference is not much different, so that the later comparison can be as expected.

The Economy Bus departure route from Purabaya Terminal to Arjosari Terminal has 4 fleets which take turns departing to deliver passengers to Malang City, the fleet includes: PO. Restu, PO. Tentrem, PO. Malinda, and PO. Akas Green. Similarly, the train route for the departure of Surabaya - Malang has a special fleet of 2 types of trains, the fleet includes: Train. Upgrading and KA. Tumapel. More details can be seen in the following table.

Table 1. Number of Bus and Train Fleets

\begin{tabular}{|l|c|}
\hline \multicolumn{1}{|c|}{ Bus } & \multicolumn{1}{c|}{ Train } \\
\cline { 1 - 1 } PO. Restu & \multirow{2}{*}{ KA. Penataran } \\
\cline { 1 - 1 } PO. Tentrem & \multirow{2}{*}{ KA. Tumapel } \\
\hline PO. Malinda & \\
\hline PO. Akas Green & \\
\hline
\end{tabular}

Source: Transportation Agency Prov. East Java \& Surabaya City Transportation Agency, 2019

1. Bus and Rail Mode Users Characteristics

The grouping of data was taken based on the results of an interview survey through a questionnaire conducted on 330 people who had used the mode of Bus and Rail Mode route Surabaya - Malang.

Table 2. Characteristics of Users of Bus and Rail Mode

\begin{tabular}{|l|l|l|}
\hline No. & \multicolumn{1}{|c|}{ Variable } & \multicolumn{1}{|c|}{ Analysis Results (\%) } \\
\hline 1. & Gender & $-\mathbf{6 0 \%}$ Women \\
& & $-40 \%$ Male \\
\hline 2. & Age & $\checkmark 31 \%$ are $18-25$ years old \\
& & $\checkmark \mathbf{5 1 \%}$ are $\mathbf{2 6}-\mathbf{3 5}$ years old \\
& & $\checkmark 14 \%$ are $36-45$ years old \\
& & $\checkmark 4 \%$ are $>46$ years old \\
\hline 3. & Last Education & $-30 \%$ High School \\
& & $-13 \%$ D3 \\
\hline 4. & Profession & $\checkmark \mathbf{5 7 \%}$ S1/S2/S3 \\
& & $\checkmark \mathbf{4 3 \%}$ Private Employees \\
& & $\checkmark 5 \%$ Entrepreneur \\
& & $\checkmark 13 \%$ Student \\
\hline 5. & Income & $\checkmark 30 \%$ Etc. \\
\hline
\end{tabular}


THE SPIRIT OF SOCIETY JOURNAL

International Joumal of Society Development and Engagement

ISSN : 2597-4777 (Online) - ISSN : 2597-4742 (Print)

This work is licensed under a Creative Commons Attrib ution-ShareAlike 4.0 International License.

\begin{tabular}{|c|c|c|}
\hline & & 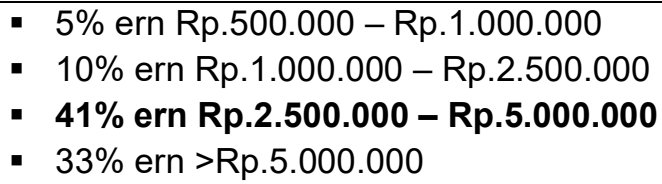 \\
\hline 6. & Purpose of The Trip & $\begin{array}{l}\checkmark \quad 19 \% \text { for Business / work } \\
\checkmark \quad 12 \% \text { for Education } \\
\checkmark \quad \mathbf{5 2 \%} \text { for Vacation / recreation } \\
\checkmark \quad 12 \% \text { for Personal / return home } \\
\checkmark 5 \% \text { Etc. }\end{array}$ \\
\hline 7. & Intensity of Use & $\begin{array}{l}\text { - } \mathbf{5 3 \%} \text { more often use the bus } \\
\text { - } 47 \% \text { more often use trains }\end{array}$ \\
\hline 8. & $\begin{array}{l}\text { Reasons to use } \\
\text { Modes }\end{array}$ & $\begin{array}{l}\checkmark \text { 15\% Time Considerations / Speed } \\
\checkmark 21 \% \text { Safety Considerations } \\
\checkmark 23 \% \text { Comfort Considerations } \\
\checkmark \text { 35\% Ease of Consideration } \\
\checkmark 6 \% \text { Cost considerations }\end{array}$ \\
\hline
\end{tabular}

Source: Survey Results, 2020

2. Difference Logit Model

The mode selection model between the Railroad and Bus modes on the way from Surabaya - Malang, can be explained in the difference binomial logit model with the difference utility function as follows:

$$
\text { UKereta - UBus }=-1,77618-0,00016 \times 1+0,00983 \times 2+0,00077 \times 3
$$

Where

$\mathrm{X} 1=$ Difference in cost

$\mathrm{X} 2$ = Difference in travel time

X3 $=$ Difference in scheduled departures

Then after the utility difference function is obtained, this equation is used as a probability function. From this modeling it can be concluded that the attribute / variable X2 (travel time) is the attribute / variable that most influences the mode selection.

3. Model Sensitivity

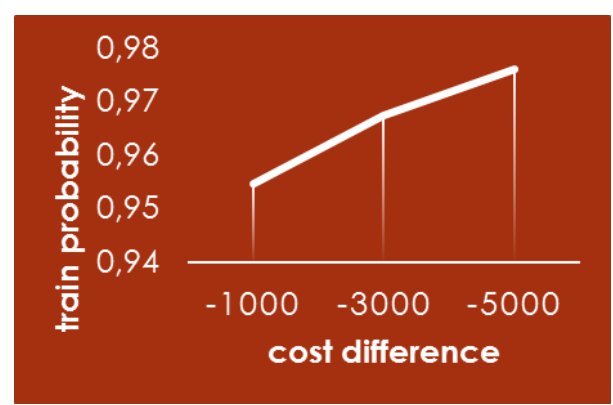

Figure 2. Graph of sensitivity to travel costs

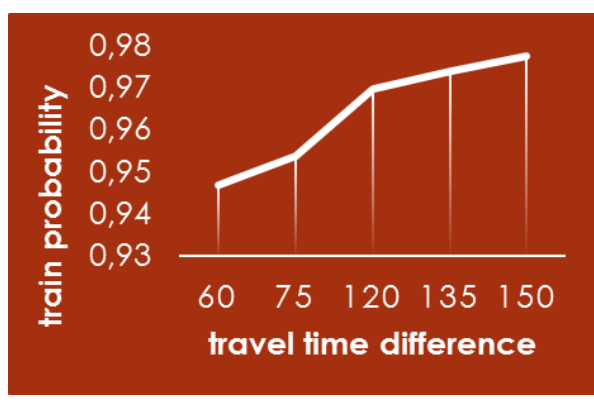

Figure 3. Graph of sensitivity to travel time 


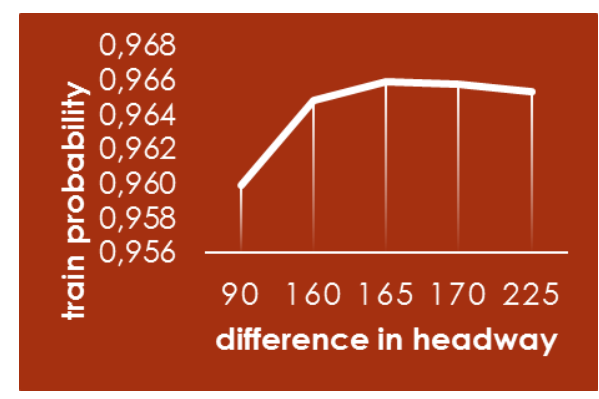

\section{Figure 4. Graph of sensitivity to scheduled departure}

From the graph above it can be concluded as follows:

a. Sensitivity to travel costs, the possibility of respondents prefer to use the train mode is greater than the Bus.

b. Sensitivity to travel time, the possibility of respondents prefer to use the mode of Train is greater than Bus.

c. Sensitivity to the departure schedule (headway), the possibility of respondents choosing to use the train mode will be greater than the Bus, if the difference in the headway is between 90-165 minutes. However, if the difference in headway is above 165 minutes, the respondent will switch to choosing Bus mode.

\section{CONCLUSION}

From the results of an analysis of 330 respondents Bus and Train users can be concluded as follows:

1. The characteristics of users of the Surabaya-Malang bus and train routes are mostly female $(60 \%)$, the majority are $26-35$ years old $(51 \%)$, the majority of the last education is S1 / S2 / S3 (57\%), the majority of jobs are in the private sector (43\%), the majority of income is between Rp.2,500,000 - Rp.5,000,000 (41\%), the majority has the intention of traveling for vacation / recreation (52\%), the intensity of use is more frequent using Bus $(53 \%)$ than Train, the reason for using majority mode is because of convenience considerations (35\%).

2. Logistic regression and binomial logit difference analysis results, it can be concluded that, attribute / variable X2 (travel time) is the attribute / variable that most influences the mode selection.

3. Results of sensitivity analysis can be concluded as follows:

a. Sensitivity to travel costs, the possibility of respondents prefer to use the train mode is greater than the Bus.

b. Sensitivity to time, the possibility of respondents prefer to use the mode of Train is greater than Bus.

c. Sensitivity to the departure schedule (headway), the possibility of respondents choosing to use the train mode will be greater than the Bus, if the difference in the headway is between $90-165$ minutes. However, if the difference in headway is above 165 minutes, the respondent will switch to choosing Bus mode. 


\section{REFERENCES}

Tamin,O.Z.2000. Perencanaan dan Pemodelan Transportasi Edisi kedua. Bandung: ITB.

Harries S., 1976, State-of-the-art review of Urban Transportation Concepts and Public Attitudes, US Department of Transportation, Washington. Tamin,O.Z.2000. Perencanaan dan Pemodelan Transportasi Edisi kedua. Bandung: ITB.

Harries S., 1976, State-of-the-art review of Urban Transportation Concepts and Public Attitudes, US Department of Transportation, Washington.

Miro, Fidel., (2005). Perencanaan Transportasi. Erlangga, Jakarta.

Morlok, Edwar K., (1995). Pengantar Teknik dan Perencanaan Transportasi. PT. Gelora Aksara Pratama, Jakarta.

Dinas Perhubungan Provinsi Jawa Timur. 2012-2032. Tataran Transportasi Wilayah Provinsi Jawa Timur. Surabaya.

Priyambodo. 2018. Analisis Korelasi Jumlah Kendaraan dan Pengaruhnya Terhadap PDRB di Provinsi Jawa Timur. Surabaya: Warta Penelitian Perhubungan 30 (59-65).

Rangkuti, M. S., \& Sugiri, A. 2014. Kajian Karakteristik Preferensi Penggunaan Moda transportasi Pribadi dan Publik Kasus: Perjalanan Harian ke UNDIP Tembalang. Jurnal Teknik PWK III (4):1-15.

Salim, H.A. Abbas. 2000. Manajemen Transportasi. Jakarta: PT Raja Grafindo Persada.

Nasution, A. 1996. Menajemen Transportasi. Jakarta: Ghalia Indonesia.

Miro, F. 2005. Perencanaan Transportasi untuk Mahasiswa Perencana dan Praktisi. Jakarta: Erlangga.

Kamaludin, Rustian. 2003. Ekonomi Transportasi (karakteristik, teori, dan kebijakan). Ghalia Indonesia. Jakarta.

Sukarto, Haryono. 2006. Transportasi Perkotaan dan Lingkungan. Jurusan Teknik Sipil-Universitas Pelita Harapan. Banten.

Ortuzar, J. D. and Willumsen, L. G. (1994). Modelling Transport. Second Edition, John Wiley \& Sons.

Permain, D, and Swanson, J. 1991. Stated Preference Techniques: A Guide To Practice. Second edition, Steer Davies Gleave and Hague Consulting Group.London.

Sugiyono. 2010. Metodologi Penelitian Pendidikan (Pendidikan Kualitatif, Kuantitatif, dan R\&D).Bandung,Alfabeta.

(C) 2020 by the authors. Submitted for possible open access publication under the terms and conditions of the Creative Commons Attribution (CC BY SA) license (https://creativecommons.org/licenses/by-sa/3.0/). 